\title{
Implementation of P\&O Algorithm - MPPT Technique for Photovoltic Application
}

\author{
S. Sherine, K. Sakthivel, Anitha. S
}

\begin{abstract}
This paper presents the generation and execution of the sun arranged photovoltaic module using MATLAB/Simulink. The PV/IV Characteristics are gotten for diverse estimations of daylight based Isolation keeping the temperature relentless. Evaluation of component execution of PVmodel using $P \& O$ considering PI.The Implementation of control framework is used as a piece of pushpull converter. The customary kind of pushpull converter doesnot convey high adequacy in light of trading disasters, transformer adversities and yield swell is also make. The proposed sort overcome each one of the adversities. The theoretical examination of the proposed converter is documented by delight and test result
\end{abstract}

Keywords:photovoltaic module, pushpull converter, (MPPT) calculation. .

\section{INTRODUCTION}

To fight a far reaching temperature support and interchange issues joined with fossil fills, United states must change to renewable imperativeness sources like sunlight,wind,biomass,mini hydro and tidal power. All renewable essentialness advancements are not fitting to all applications or zones, there are regular issues to be considered. A study by the Union of concerned Scientists and three other national affiliations, America's Energy choices, found that despite when strict natural standards are used for surveying renewable imperativeness broadens, these essentialness sources can give more than half of the US imperativeness supply by the year 2030. [1],[3],[5]

Table I Electrical Parameters Of The Pv Cell

\begin{tabular}{|l|l|}
\hline Maximum power & $P_{\max }=250 w p$ \\
\hline Voltage at MPP & $V_{\operatorname{mpp}}=2.9$ \\
\hline Current at MPP & $I_{\operatorname{mpp}}=7.1$ \\
\hline Open circuit voltage & $V_{o c}=35.8$ \\
\hline Short circuit current & $I_{s c}=8.3$ \\
\hline $\begin{array}{l}\text { Temperature } \\
\text { Coefficient Of } I_{S C}\end{array}$ & $\alpha=-0.05 /$ \\
\hline
\end{tabular}

Revised Manuscript Received on August 22, 2019.

S.Sherine Assistant Professor ,Department of EEE,Bharath Institute of Higher Education \& Research,TamilNAdu

K.Sakthivel Assistant Professor, Department of EEE ,Bharath Institute of Higher Education \& Research,TamilNAdu

Anitha.S Assistant Professor, Department of EEE,Bharath Institute of Higher Education \& Research,TamilNAdu
Due to the cognizant issues of environmental defilement and fossil fuel usage, photovoltaic (PV) imperativeness has perceived huge thought as a wellspring of renewable essentialness. Renewable imperativeness headways today are all around made,strong, and cost centered with the standard fuel generators. The cost of renewable imperativeness advances is on a falling example and is depended upon to fall further as interest and era increases. One of the purposes of interest offered by (RES) is their ability to give reasonable force in locales not served by the standard power cross section. The creating business segment for renewable essentialness advancements has realized a quick improvement in the need of power equipment. A substantial part of the renewable essentialness propels produce DC power and in this manner control equipment and control apparatus are required to change over the $\mathrm{DC}$ into $\mathrm{AC}$ power $\mathrm{PV}$ panel modeling.

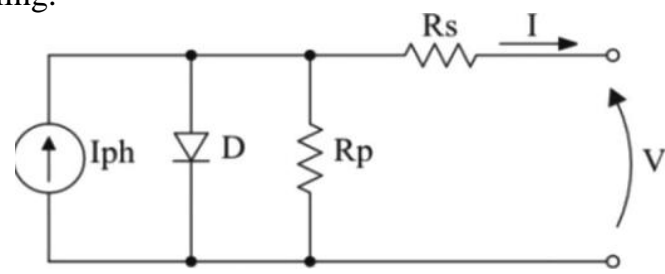

The Equivalent circuit of a PV cell which is showed up in Fig1 .The current is antiparallel joined with diode and $\mathrm{Rs}$ (series resistance)and $\mathrm{Rp}$ (parallel resistance). The yield current of one PV relative model relies on upon PV board reenactment, The photovoltaic cell yield voltage is basically a part of the photocurrent which is on a very basic level managed by weight current depending upon the daylight based light level in the midst of the operation.

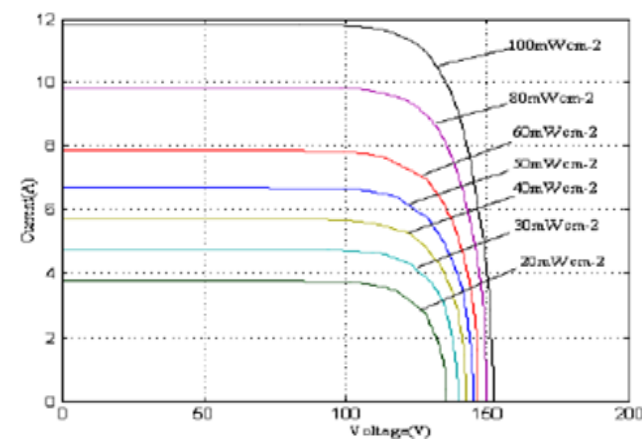

Fig. 2 VI curve with different Irradiation 


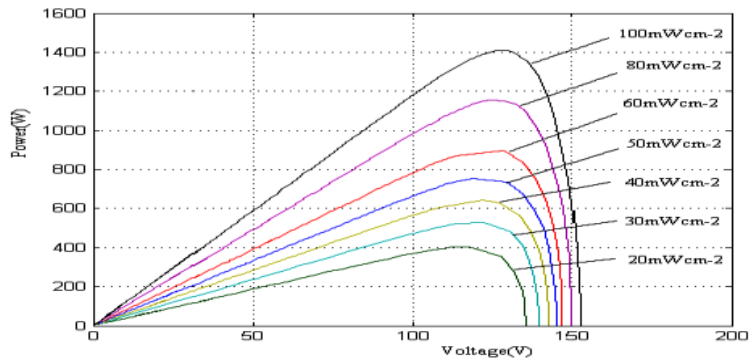

Fig. 3.PV curve with different Irradiations

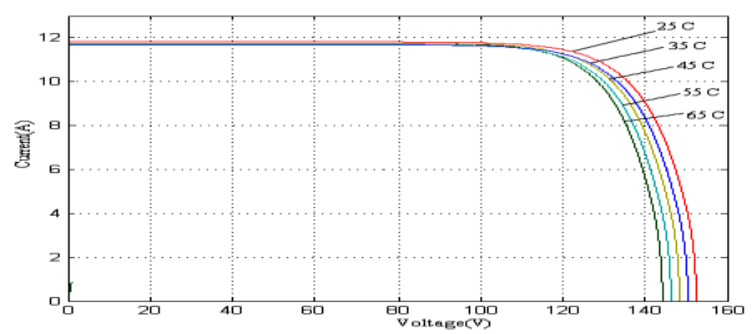

Fig. 4. VI curve with different Temperatures

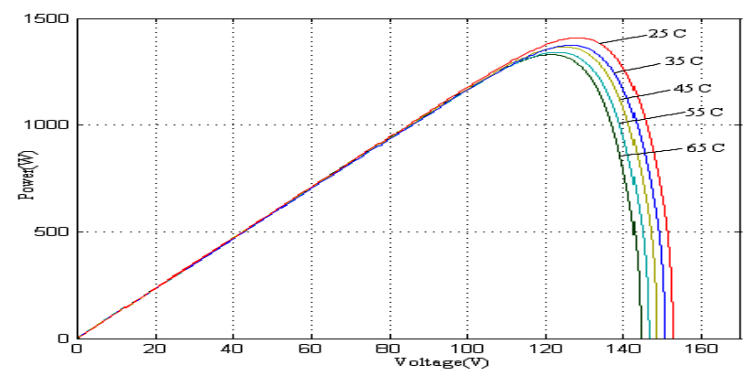

Fig. 5. PV curve with different temperatures

A Voltage source is used as a model the capacitance that stores and imbued current from the PV board identifies with as an integrator. The PV electrical parameters are presented in Table I. [2 ],[4],[6]

\section{MPPT TECHNIQUE}

\section{A.P\&O Based on PI and P\&O}

It just sense the current and voltage of load up for particular time and enroll minute force. The yield terminal voltage of the $\mathrm{PV}$ cell Incrementing (or) Decrementing periodically by $\mathrm{P} \& \mathrm{O}$ framework. It basically take a gander at the power procured in the present cycle with the power of the previous one $(\mathrm{dP} / \mathrm{dV})$. As voltage varies power augments and control structure changes the working point in that bearing and the working point adjusts in reverse course. The voltage is varied for a predictable rate once the bearing is changed . It act Fast response, lesschange, tireless state are adjusted. Profitability increases as step changes as demonstrated by the partition of MPP. The going with correlation go about as , [7],[9] ,[11]

Signal $(\mathrm{d} P / \mathrm{d} V) \times(-\mathrm{kr})=\mathrm{d}$

Where $\mathrm{d} / \mathrm{d} \mathrm{V}$ identifies with the auxiliary of $\mathrm{P}$ in association with $\mathrm{V} \mathrm{kr}$ is steady, and $\mathrm{d}$ is the commitment

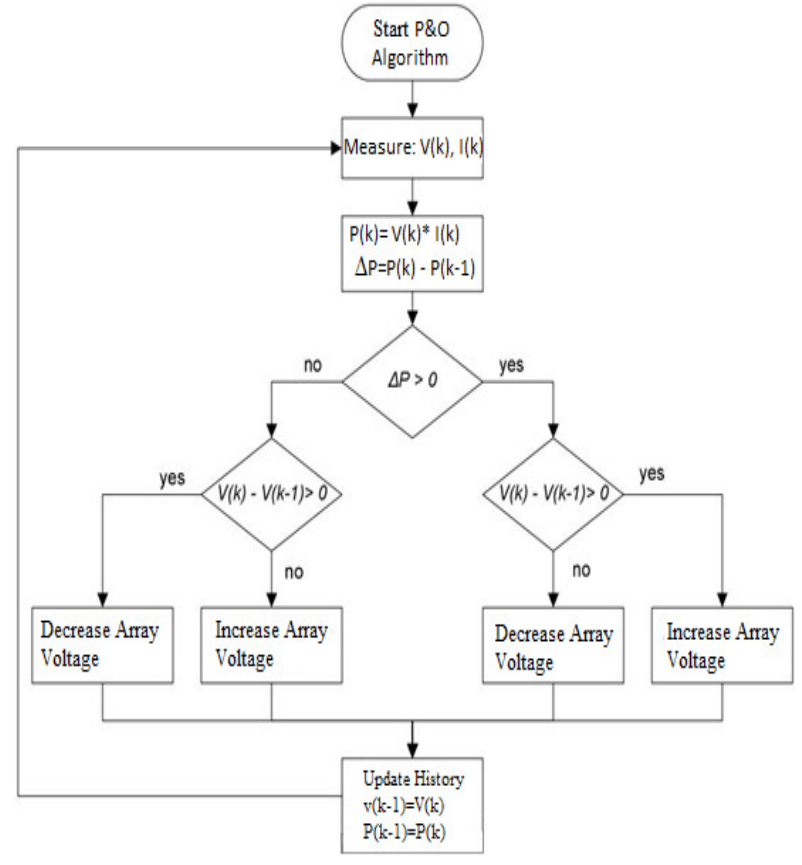

Fig. 6. Flowchart of $\mathrm{P} \& \mathrm{O}$

\section{PUSHPULL CONVERTER}

Pushpull converter is one gathering of DC-DC converter.It is suitable to up the voltage from low to high voltage.This converter may be used as a piece of conjunction with a high repeat transformer to bolster the yield voltage with the advantage of giving division between the information and yield stage. It is used to change over a quality from $12 \mathrm{v}$ data voltage.The standard portion used as a piece of this converter is a high repeat transformer,integrate circuit and full augmentation rectifier.It in like manner use two MOSFET as a changing contraption as a result of its effective evaluating and high trading speed. It will pass on definite yield regard with low influence incidents and little yield swell in light of the way that this converter have its own specific channel.

\section{CONVENTIONAL PUSH-PULL CONVERTER}

On account of the upside of less fragments, ease and separation between the PV module and the aeration and cooling system structure line the pushpull converter is utilized as a part of PV ventilating module structure. The normal kind of pushpull converter has a high repeat transformer with crucial and assistant side of transformer is used by a voltage reinforced source. In light of low data and high return voltage they convey high stepup extent which is not suitable for ventilating module system. The present source is worn to the pushpull converter which reduces the turns extent of the transformer. The Copper disaster and spillage of transformer parts are thick in light of the way that the key voltage of transformer is greater than the source voltage data by a Boost inductor. The yield of dc-dc converter needs a touch of decoupling capacitor which lies in the extent of $10-20 \mu \mathrm{F}$.

The beat with parity (PWM) controls dc join voltage and yield current of inverter in two stage game plan. The repeat of the ventilation system structure is inclined by voltage swell with the voltage swell of capacitor.

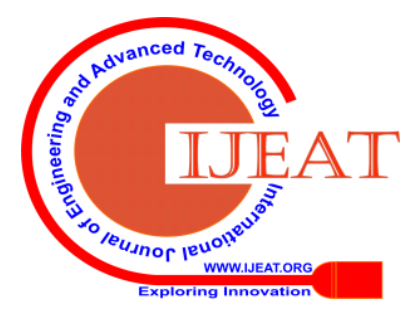


The present empowered converter is more suitable for renewable imperativeness system than the voltage-fed converter[8],[10], ,[12]

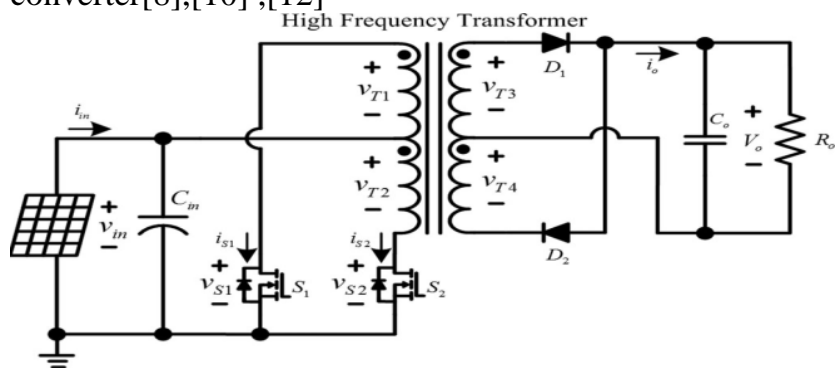

Fig. 7. Circuit diagram of Conventional pushpull converter

\section{PROPOSED PUSHPULL CONVERTER}

The examination of standard and proposed pushpulls converter table II s given underneath. In light of hard trading the conventional pushpull converter has trading incidents. The high voltage of the aeration and cooling system cross section line in PV module convey low voltage of high walk up extent which may happen transformer adversities. The proposed pushpull converter exhibited as takes after. The circuit has a section, for instance, key trading devices $(\mathrm{S} 1, \mathrm{~S} 2)$, a help inductor Last, a Voltage doubler.

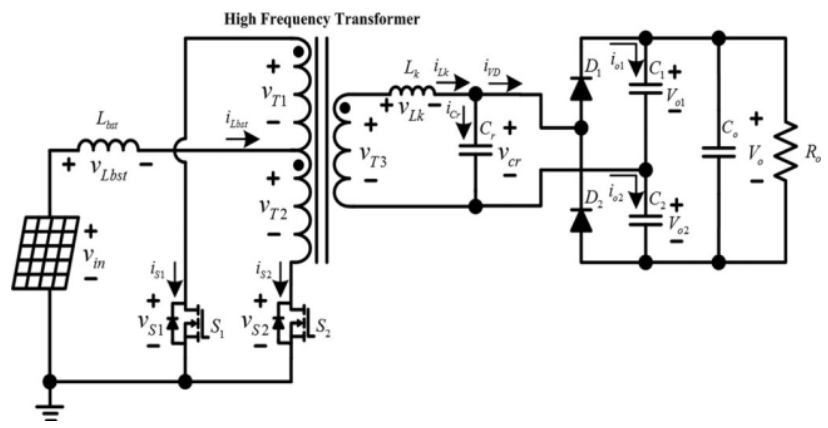

Fig.8. Circuit diagram for ProposedPushpull converter.

A.

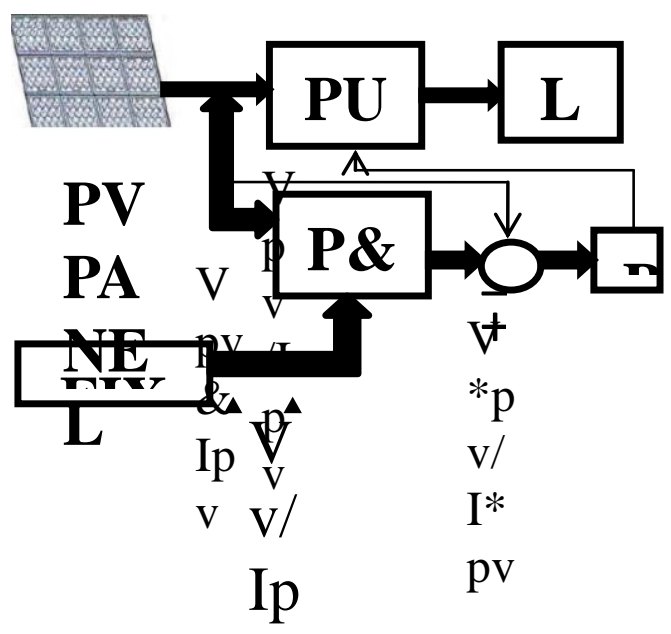

V

Fig.9, Block Diagram of Proposed work
This model is made just in Matlab, in light of numerical mathematical statements that characterize the photovoltaic cell. From the work of this venture, a capacity in Matlab has been created which computes the present module from information of voltage, sun oriented radiation and temperature. Setting the consistent temperature or radiation, bends IV and PV will be gotten. From another script additionally ascertains the most extreme force point. The usage of a summed up photovoltaic model utilizing Matlab/Simulink programming bundle, which can be illustrative of PV cell, module, and cluster for simple use on reproduction stage. [13], [15], [17]

\section{A. SPECIFICATION OF PUSHPULL CONVERTER}

$\square$ Input voltage $=40 \mathrm{~V}$

Output voltage $=400 \mathrm{~V}$

Boost Inductor $=300 \mathrm{e}-3$

$\square$ Secondary spillage inductance $=7 \mathrm{e}-3$

Resonant capacitor $=3 \mathrm{e}-9$

$\square$ Switching Frequency $=50-100 \mathrm{kHz}$

Pulse width $=$ half

$\square$ Maximum power $=250 \mathrm{~W}$

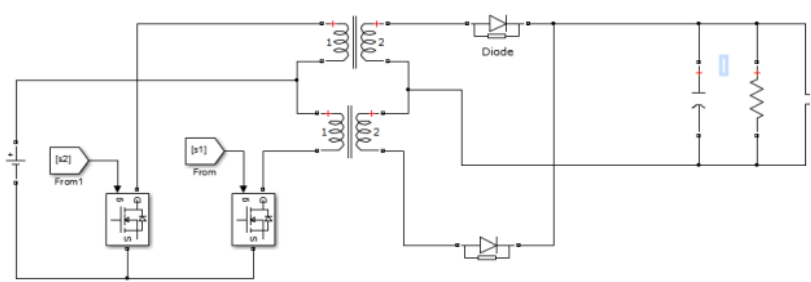

Fig 10. Simulation result for conventional pushpullconverter

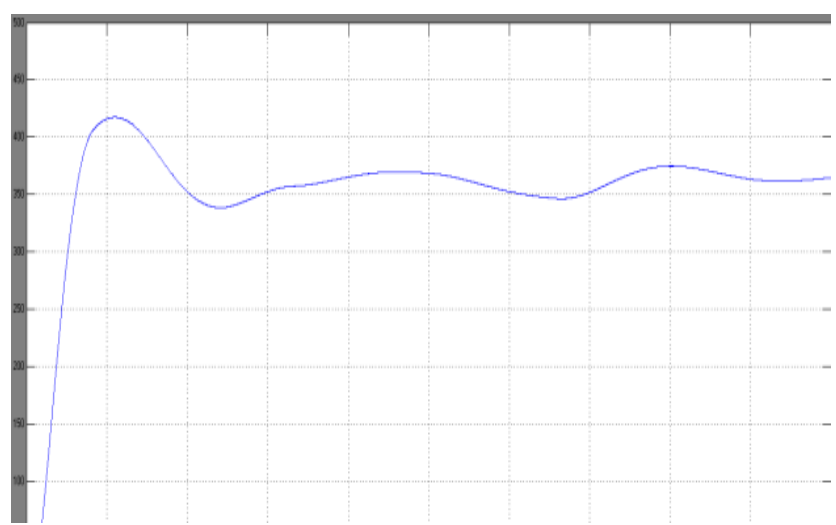

Fig.11, Output waveform for conventional pushpull converter

\section{RECREATION RESULT}

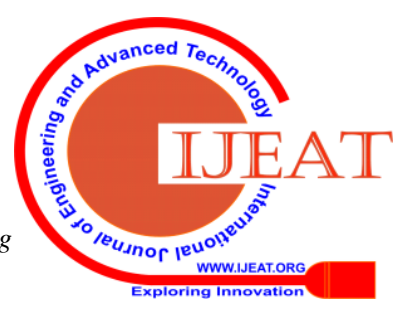




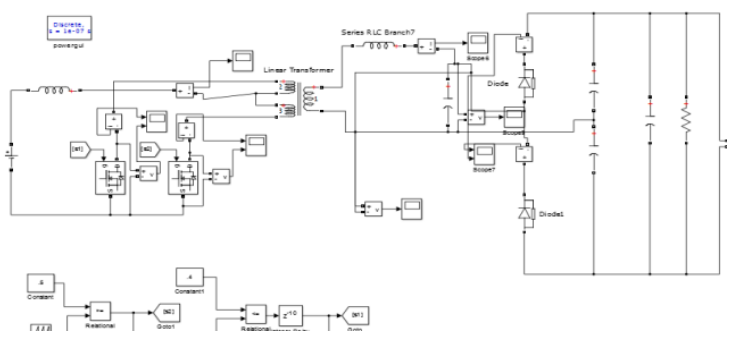

Fig.12, Simulation result for proposed pushpull converter

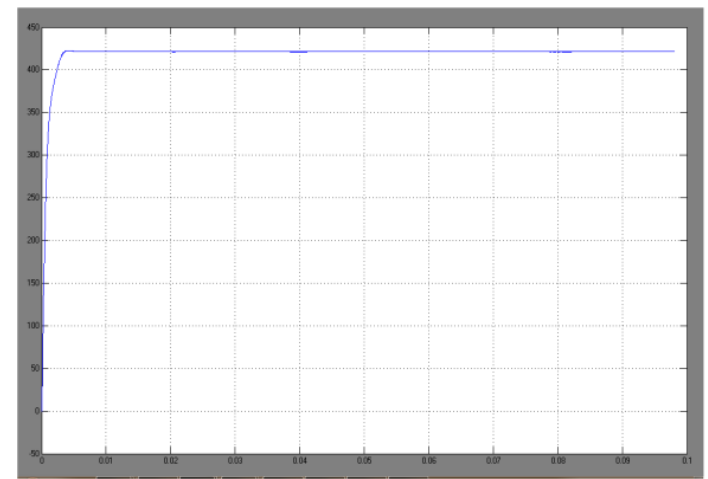

Fig.13, Output waveform for proposed pushpull converter

\section{DIVERSION RESULT}

This model is made just in Matlab, in light of numerical scientific articulations that describe the photovoltaic cell. From the work of this wander, a limit in Matlab has been made which registers the present module from data of voltage, sun arranged radiation and temperature. Setting the predictable temperature or radiation, twists IV and PV will be gotten. From another script also discovers the most great power point. The use of a summed up photovoltaic model using Matlab/Simulink programming pack, which can be illustrative of PV cell, module, and group for basic use on proliferation stage. [14],[16],[18]

\section{A. SPECIFICATION OF PUSHPULL CONVERTER}

$\square$ Input voltage $=40 \mathrm{~V}$

$\square$ Output voltage $=400 \mathrm{~V}$

$\square$ Boost Inductor $=300 \mathrm{e}-3$

$\square$ Secondary spillage inductance $=7 \mathrm{e}-3$

$\square$ Resonant capacitor $=3 \mathrm{e}-9$

$\square$ Switching Frequency $=50-100 \mathrm{kHz}$

$\square$ Pulse width $=$ half

$\square$ Maximum power $=250 \mathrm{~W}$

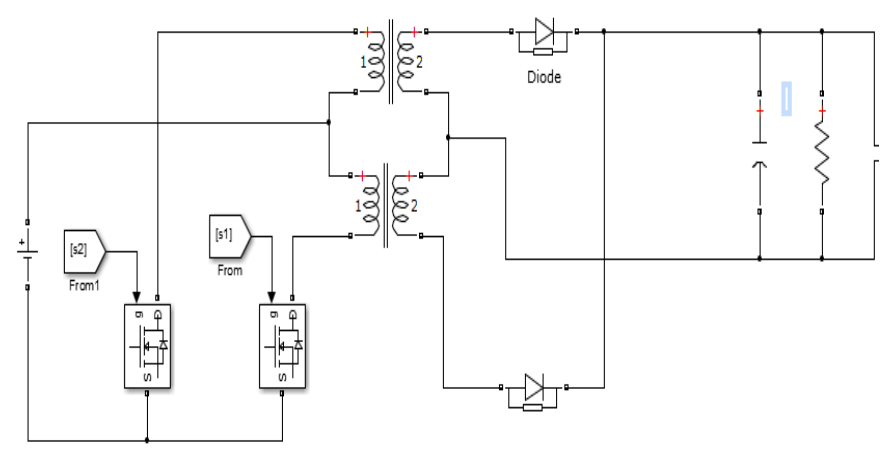

Fig. 10. Simulation result for conventional pushpull converter

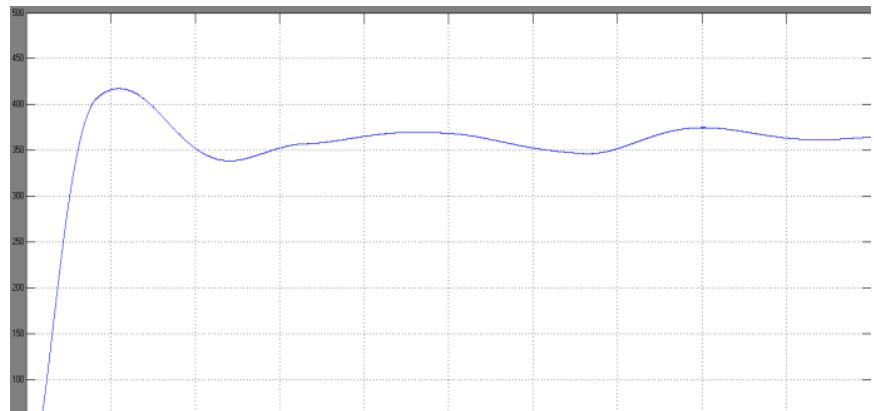

Fig.11, Output waveform for conventional pushpull converter

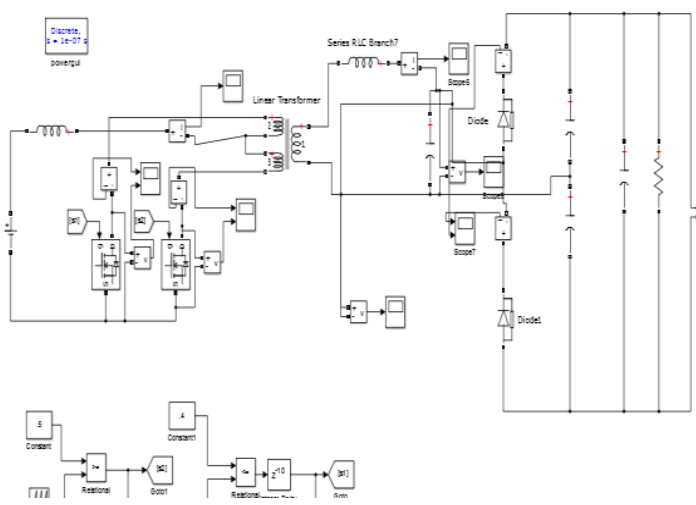

Fig.12, Simulation result for pushpull converter

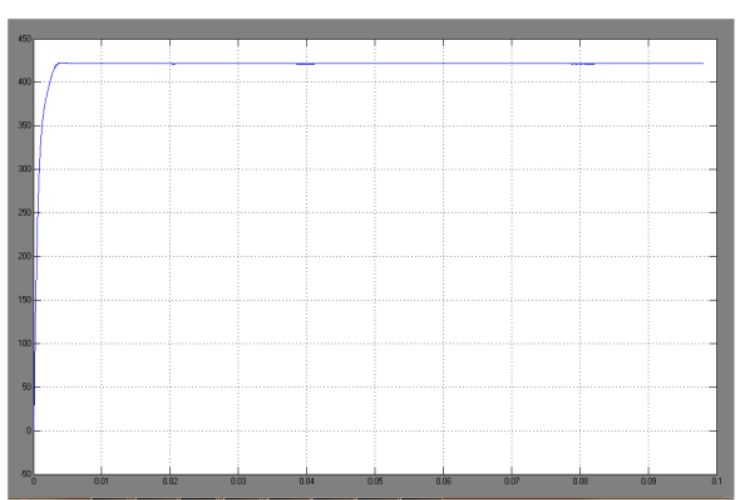

Fig.13, Output waveform for push pull converter

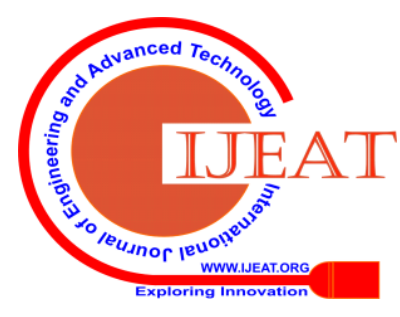




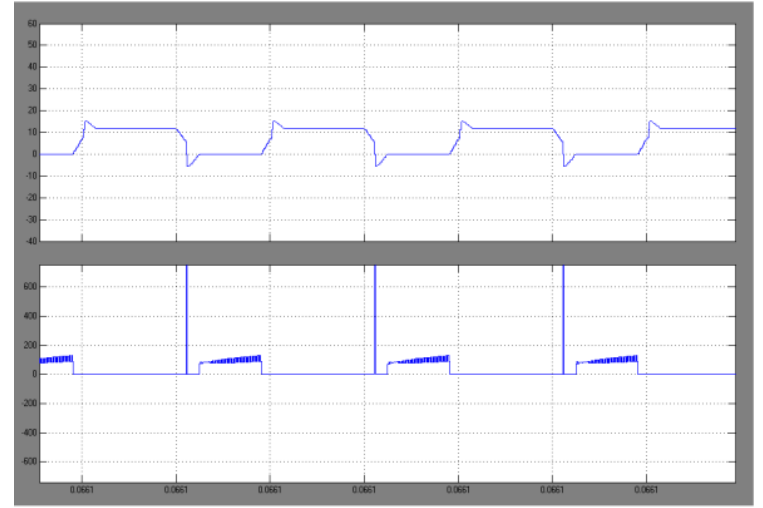

Fig.14, Simulation results of switch s1 current,voltage waveform

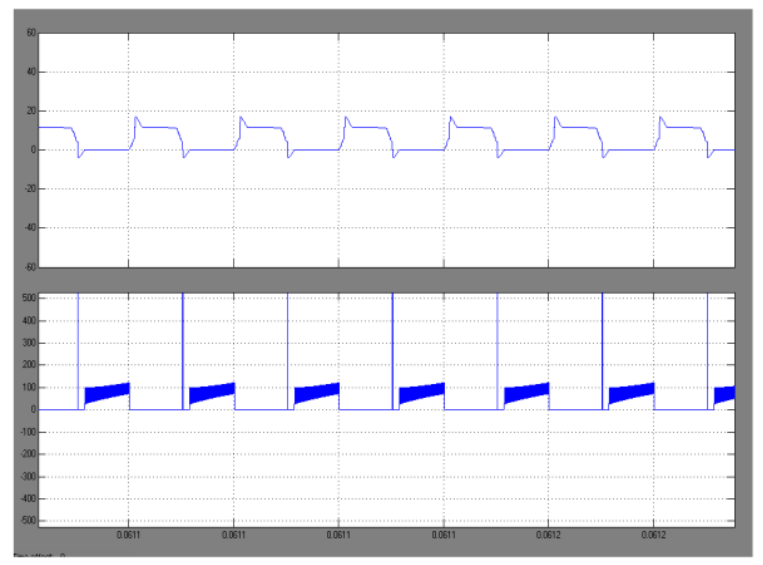

Fig.15 Simulation result of switch s2, current, voltage waveform

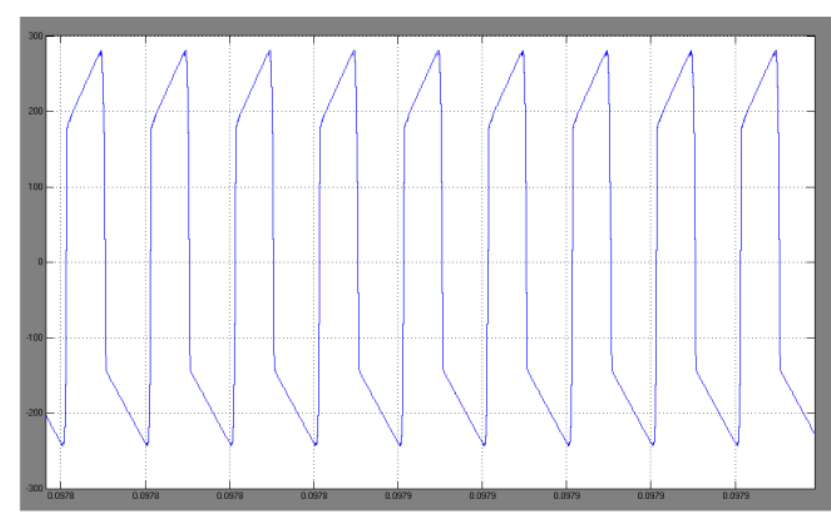

Fig.16 Simulation results for Resonant capacitor voltage

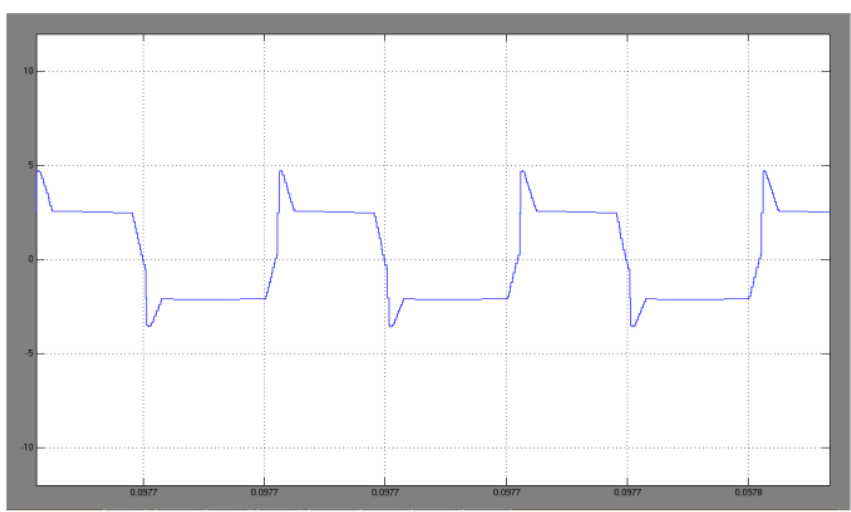

Fig.17, Simulation results of leakage inductor current waveform.

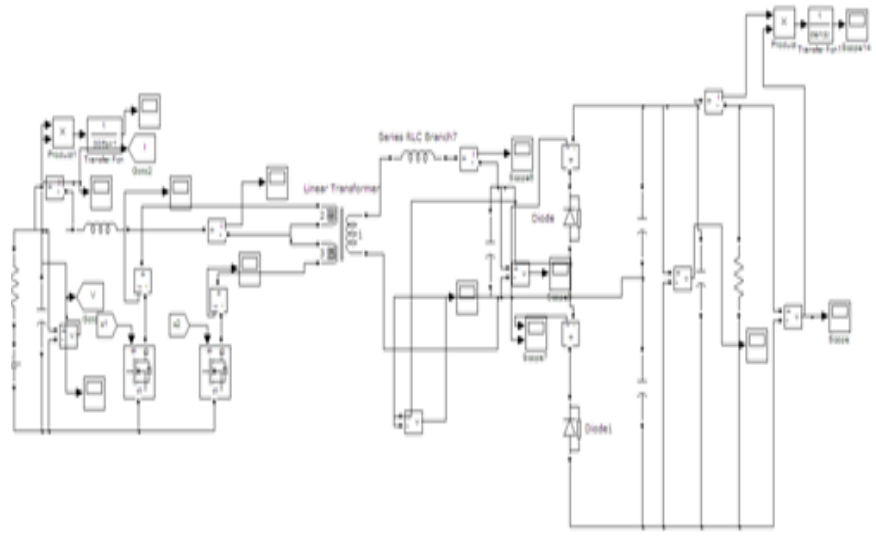

Fig.18. Simulation diagram of proposed pushpull converter with MPPT

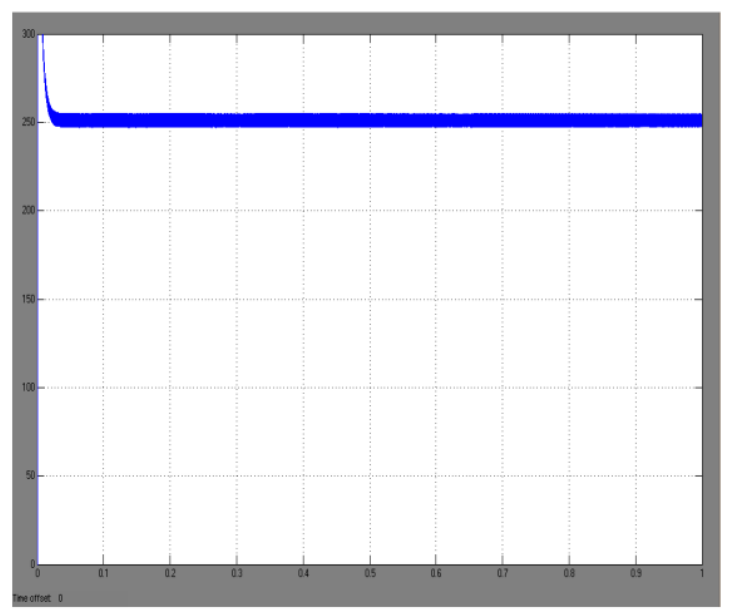

Fig.19.Output result of PV power waveform with MPPT.

\section{CONCLUSION}

The PV aerating and cooling module application is proposed in the softswitching of pushpull converter. The switches in the ZCS conditions turns ON and ZVS murders in Primary side .220Vrms of dc-cooling inverter give $400 \mathrm{~V}$ of yield voltage in proposed converter.Hence the result is avowed by reenactment and verifie d $250 \mathrm{~W}$ probably. [19],[21], [20],

\section{REFERENCES}

1. Sharma, R.K., Irusapparajan, G. \& Periyaazhagar, D. 2019, "Three-phase symmetric cascading Z-source seven levels multilevel inverter excited by multi carrier sinusoidal pulse width modulation scheme", International Journal of Innovative Technology and Exploring Engineering, vol. 8, no. 10, pp. 4269-4274.

2. Velavan, R., Bharanidharan, S. \& Sheeba, B. 2019, "EMF pollution Causes, effects and protection", International Journal of Innovative Technology and Exploring Engineering, vol. 8, no. 9 Special Issue 3, pp. 1166-1168.

3. Saravana, S., Balaji, S., Arulselvi, S. \& John Paul Praveen, A. 2019 "Reliable power quality monitoring and protection system", International Journal of Innovative Technology and Exploring Engineering, vol. 8, no. 9 Special Issue 3, pp. 644-645.

4. Tamil Selvan, S. \& Sundararajan, M. 2019, "Performance Parameters of 3 Value 8t Cntfet Based Sram Cell Design Using H-Spice", International Journal of Recent Technology and Engineering, vol. 8, no. 2 Special issue 5, pp. 22-27.

Published By:

Blue Eyes Intelligence Engineering 
5. Jac Fredo, A.R., Abilash, R.S., Femi, R., Mythili, A. \& Kumar, C.S. 2019, "Classification of damages in composite images using Zernike moments and support vector machines", Composites Part B: Engineering, vol. 168, pp. 77-86.

6. Kathiravan, P. \& Govindaraju, C. 2019, "Design and evaluation of ultra gain isolated DC-DC converter for photovoltaic system", International Journal of Engineering and Advanced Technology, vol. 8, no. 5, pp. 2646-2651.

7. Kripa, N., Vasuki, R. \& Kishore Kanna, R. 2019, "Realtime neural interface controlled au-pair BIMA bot", International Journal of Recent Technology and Engineering, vol. 8, no. 1, pp. 992-994.

8. Mohanraj, Meenaa Kumari, M., Philomina, S. \& Jasmin, M. 2019, "In-situ humidity measurement of hydrogen fuel cell car using MEMS sensor", International Journal of Recent Technology and Engineering, vol. 8, no. 1, pp. 41-43.

9. Velmurugan, T. \& Prakash, S. 2019, "Artificial intelligent based distribution automation of swift fault detection isolation and power restoration for HT network", International Journal of Innovative Technology and Exploring Engineering, vol. 8, no. 6, pp. 1-6.

10. Dwarakesh, K. \& Prem Kumar, G. 2019, "Five-level inverter based sequential boost system using fuzzy logic controller", International Journal of Innovative Technology and Exploring Engineering, vol. 8, no. 6, pp. 12-19.

11. Anne Gifta, A. \& Hemavathi, G. 2019, "Analysis of grid tied solar PV system using ANFIS Algorithm", International Journal of Innovative Technology and Exploring Engineering, vol. 8, no. 6, pp. 312-316.

12. Jayavel, R., Rangaswamy, T.R. \& Prakash, S. 2019, "Efficient grid management system with renewable and conventional power sources", International Journal of Innovative Technology and Exploring Engineering, vol. 8, no. 6, pp. 287-289.

13. Hemavathi, G. \& Maheshwaran, S. 2019, "Proportional resonan controlled high gain step-up converter system with improved response", International Journal of Innovative Technology and Exploring Engineering, vol. 8, no. 6, pp. 317-323.

14. Periyaazhagar, D. \& Irusapparajan, G. 2019, "Design and completion of asymmetric single phase 27 level cascaded mli for various pwm scheme", International Journal of Innovative Technology and Exploring Engineering, vol. 8, no. 6, pp. 792-797.

15. Mahalakshmi, V. \& Vijayaragavan, S.P. 2019, "PV based power electronic converters for high voltage DC applications", International Journal of Recent Technology and Engineering, vol. 7, no. 6, pp. 670-674.

16. Irusapparajan, G., Periyaazhagar, D., Prabaharan, N. \& Rini Ann Jerin, A. 2019, "Experimental verification of trinary DC source cascaded h-bridge multilevel inverter using unipolar pulse width modulation", Automatika, vol. 60, no. 1, pp. 19-27.

17. Sangeetha, G., Sherine, S., Arputharaju, K. \& Prakash, S. 2019, "On Line Monitoring of Higher Rated Alternator using Automated Generator Capability Curve Administer", Proceedings of the IEEE International Conference on \&amp;quot;Recent Trends in Electrical, Control and Communication\&amp;quot; RTECC 2018, pp. 176.

18. Bycil, V.J. \& Wiselin, M.C.J. 2019, "Modeling and analysis of vibration energy harvesting system using piezo stack", International Journal of Mechanical and Production Engineering Research and Development, vol. 9, no. Special Issue 1, pp. 523-533.

19. Sripada, A., Warrier, A., Kapoor, A., Gaur, H. \& Hemalatha, B. 2018 "Dynamic lateral balance of humanoid robots on unstable surfaces", International Conference on Electrical, Electronics, Communication Computer Technologies and Optimization Techniques, ICEECCOT 2017, pp. 539.

20. Srinivasan, S., Thirumalaivasan, K. \& Sivakumaran, T.S. 2018 , "Performance evaluation of double-output luo converters", Journal of Advanced Research in Dynamical and Control Systems, vol. 10, no. 10 Special Issue, pp. 870-878.

21. Karthikayen, A. \& Selvakumar Raja, S. 2018, "A skellam distribution inspired trust factor-based selfish node detection technique in MANETs", Journal of Advanced Research in Dynamical and Control Systems, vol. 10, no. 13, pp. 940-949.

\section{AUTHORS PROFILE}

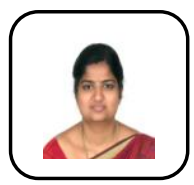

S.Sherine Assistant Professor ,Department of EEE,Bharath Institute of Higher Education \& Research,TamilNAdu

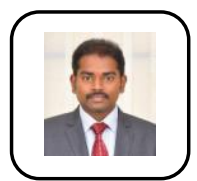

K.Sakthivel Assistant Professor, Department of EEE ,Bharath Institute of Higher Education \& Research,TamilNAdu

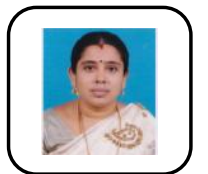

Anitha.S Assistant Professor, Department of EEE,Bharath Institute of Higher Education \& Research,TamilNAdu 